九州大学学術情報リポジトリ

Kyushu University Institutional Repository

\title{
A SUMMARY OF THE PALAEOGENE STRATIGRAPHY OF NORTHERN KYUSHU
}

Matsushita, Hisamichi

Faculty of Sciences, Kyushu University

https://doi.org/10.5109/1524103

出版情報：九州大學理學部紀要：Series D, Geology. 3 (2), pp.91-107, 1949-11-10. Faculty of Science, Kyushu University

バージョン：

権利関係 : 


\title{
A SUMMARY OF THE PALAEOGENE STRATIGRAPHY OF NORTHERN KYUSHU
}

\author{
By
}

\section{Hisamichi MatsUSHITA}

(Received April 20th 1949)

\section{Stratigraphy and Main Structure}

\section{Chikuhō coal field}

The palaeogene sediments of this field striking north-east and dipping $10^{\circ}-30^{\circ}$ east ward, attain a thickness of 2,500 meters in maximum, and are divisible into three groups which are known as the Nōgata, Ōtsuji and Ashiya groups.

The Noggata group is divided into four formations, Oyake, Honsō, Takeya and Uwaishi. They are terrestrial in origin but intercalated with marine fossiliferous strata and are composed of sandstone, shale and conglomerate.

In the basal parts of the Oyake and Uwaishi formations there are thick reddish purple formations, deposited under a special climate.

The Otsuji group overlain unconformably on the Nōgata group, is predominantly made up of sandstone with intercalated shale and seven coal seams in the upper section (the Onga formation), but in the lower section (the Ideyama formation) conglomerate is dominant, especially so in the basal part, and the formation is reddish coloured by its original character, as well as the Takeya formation.

Although silicified wood is common in all coal seams in the Nōgata and Ötsuji groups, the silicified woods standing nearly perpendicullar to the bedding plane and spreading the roots in the underlaid beds, are scarcely found in the Onga formation.

The Ashiya group is marine in origin and consists of dark grey shale and green, glauconitic sandstone. 
The fossils such as Crassatellites yabei Nagao, Glycymeris cisshuensis Makiyama and etc. are found in this group.

\section{Kokura coal field}

Though the geological sequence of this field is same as that of the Chikuho coal field, it lacks the Nogata group, so that the Otsuji group was laid directly upon the pre-Tertiary basement complex. The palaeogene sediments have a maximum thickness of 1.800 meters and are compressed into a syncline trending northnorthwest.

LOCATION OF COAL FIELDS IN KYUSHU

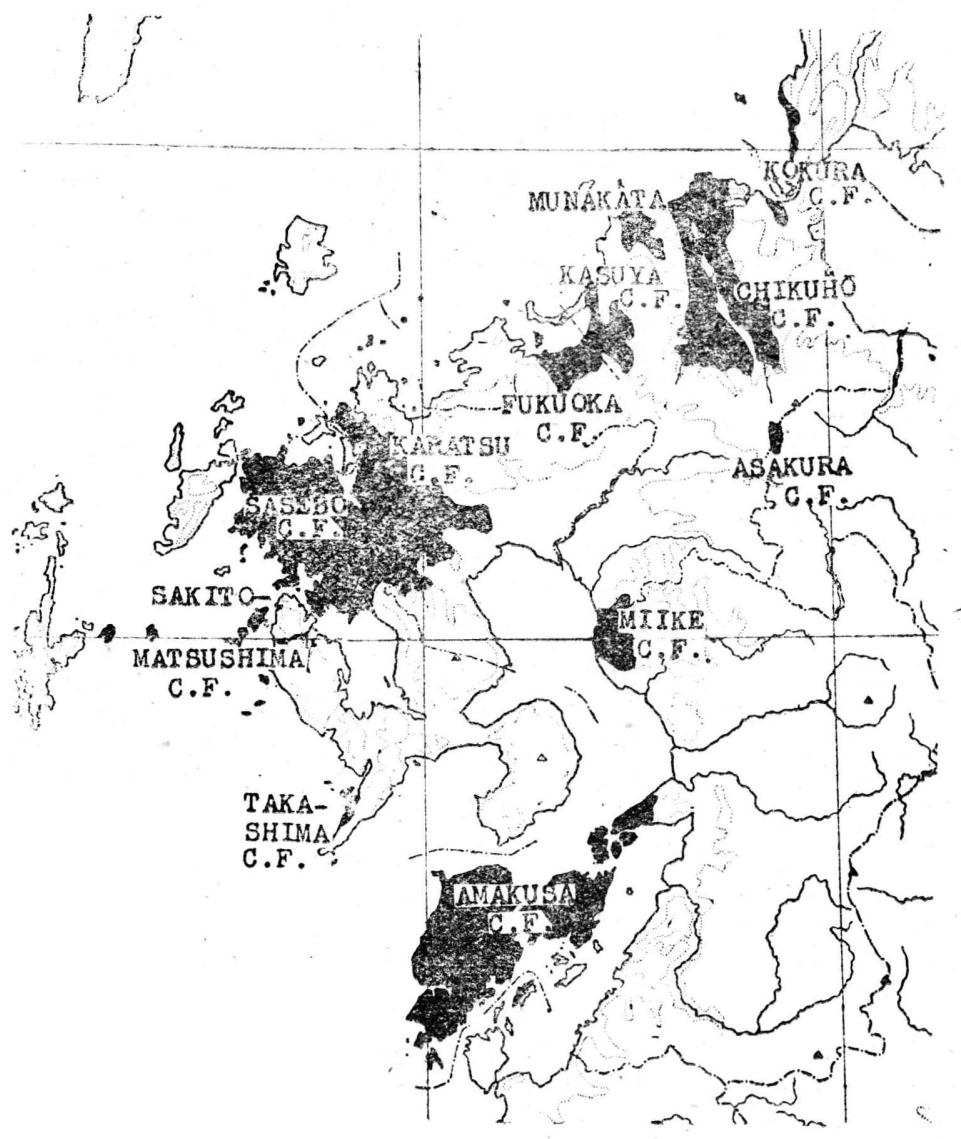




\section{Munakata coal field}

The palaeogene sediments of this field are a sequence of interbedded shale, sandstone, conglomeratic sandstone and conglomerate, and are divided into five formations, Ryōganji, Tare, Sōbaru, Ōnoi, and Ikeda formation.

The Ryōganji formation is, in general, composed of the basal conglomerate with intercalated shale and sandstone, however, in the area where porphyrite is developed as the base rock, the reddish purple formation is found in its basal part.

The Sōbaru and Ikeda formations are the coal bearing formations of this field. The upper part of the Ikeda is composed of shale and silicified fine grained sandstone called "Honeishi"

The Ōnoi consists of sandstone and conglomerate with intercalated red formation.

The formations are conformable with each other and are cut by a series of the north-northwest trending faults.

\section{Kasuya coal field}

This field lies east of the Fukuoka coal field and is sparated by a fault known as Hakata-Futsukaichi line from the latter coal field, and divided into three coal fields, the northern, southern and coastal coal fields by the interposed basement complex.

The palaeogene sediments are divisible into two groups, Shime and Kasuya and the sediments have been brocken into blocks by a series of the normal northwest striking faults.

The Kasuya group overlain on the basements is chiefly made up of sandstone and shale and are again divided into three formations, Usui, Takata and Umi.

The reddish purple formation is found in the lower part of the Usui formation and thin strata of the reddish purple sediments are also found in the Takata formation.

The Usui formation is the lowermost sediments in this field, however, in general, the Takata directly overlies unconformablly upon the basement complex.

Overlying unconformably the Kasuya group, the Shime group is developed, and the group is divided into three formations, Najima. Shinbaru and Sue.

The latter two formations are chiefly consist of white sandstone and intercalated shale and coal seams. 
Silicified woods are also common in all coal seams of the Kusuya group, especially rich in the northern coal field, but, not so in the Shime group.

\section{Fukuoka coal field}

The field is divided into three sections, Meino-hama, Saitozaki and Fukuoka proper by its geologic structures.

The palaeogene sediments in the Fukuoka proper section have been brocken by the north-west and north-south striking faults, but the structures of the sediments in the Meinohama and Saitozaki sections are semi-basin trending east to west.

The sediments of this field have a maximum thickness of about 1,400 meters, and are divisible into three groups, Fukuoka, Sawara and Meinohama in ascending order.

The reddish purple formations are found in the Nokonoshima formation. The upper part of the Sawara group, the Atago formation and the Noma group are the coal bearing formations; of which, the coal seams of the Atago are drift in origin, however, that of the Noma group is autochthonous in origin.

The Meinohama group is marine in origin and made up of medium grained glanconitic sandstone and contains such fossils as Crassatellites yabei Nagao, Callista hanzawai Nagao and Carcharodon cfr. augustidens Ag..

\section{Asakura coal field}

The palaeogene sediments of this field unconformably overlying the basement complex and overlain by andesitic volcanic rocks are found in small area. They have the north-south strikes and $\operatorname{dip} 20^{\circ}$ to the east and are dislocated by a series of normal faults striking from the north-west to the south-east.

Three groups which are known as the Akasaki, Hōshuyama and Doshi in ascending order, are contained in them.

The Doshi group is devided into two parts by a slight unconformity.

The lower division of the group, the Kawamagari formation is marine deposits containing green glauconitic thick sandstone of the upper part and thick grey shale of the lower part.

The upper division of the group is again divided into two formations, Doshi and Doshiyama. 
The Doshi formation is the main coal bearing one of this field.

The Doshiyama formation is not exposed out but found in the Hōshuyama colliery and is made up of sandstone and shale containing marine fossils such as Orthaulax japonicus, Athleta nishimurai, Athleta japonica, and Venericardia nipponica. All of them are also found from the Kawamagari formation together with Pinna asakuraensis, Phacoides cfr. pullensis, Aturia yokoyamai, Nautilus japonicus and Carcharias cfr. cuspidata.

\section{Miike coal field}

The major faults in this field are the north-south striking Komenoyama fault which bounds the field on the east and the Miyanoura fault and its pallalel ones striking from the northeasteast to southwest-west.

The palaeogene sediments resting upon basement schist series and having been covered with pleistocene gravels or volucanics, have in general, northwest strikes and dip to the southwest, and they are divided into three groups, in ascending order, Akasaki, Omuta, and Manda which are all conformable.

The Akasaki group (the Ginsui formation) contains reddish purple formation and have developed at wide area of this field.

The lower division of the Ōmuta group is known as the Komenoyama formation which is made up of white sandstone and shale containing Turritella okadai and other marine fossils.

The middle division of Ōmuta group is known as the Toka coal bearing formation.

The Manda group is predominantly sandstone, of which, the rocks of the lower part (the Katsutachi formation) are glauconitic and fossiliferous, and that of the upper part (the Yotsuyama formation) is fine grained.

The fossils obtained from the Katsutachi formation are as follow.

$$
\begin{aligned}
& \text { Crassatellites fuscus (Yokoyama) } \\
& \text { Venericardia nipponica Yokoyama } \\
& V . \quad \text { mandaica (Yokoyama) }
\end{aligned}
$$

\section{Karatsu-Sasebo coal field}

The northwest trending echelon faults known as the Kariya- 
Usizu line, bound the northeastern margin of this field.

The main structural feature of this field is a east-west tending syncline in the eastern area (Karatsu-district), however, it is gently west dipping syncline in the western area (Hokusho or Sasebo (istrict).

The major faults are normal north-west striking ones except a large reverse faults.

The palaeogene sediments of this field have a maximum thickness of 2,400 meters, and are divided into three groups, $\bar{O}$ chi, Kishima and Sasebo in ascending order.

The Ochi group occures in the northeastern margine of this field, and is again divided into three formations, Utsubogi, Yashiro and Yoshinotani in ascending order.

The Utsubogi formation is marine deposits with intercalated terestrial deposits bearing one coal seams, Kyuragi-Goshaku.

The Yashiro is also marine in origin, however, contains the reddish brown or light red formation composed of sandstone and conglomerate. The Yoshinotani is mainly made up of white sandstone having many coal seams,

The Kishima group is marine deposits being composed of thick sandstone bearing more or less glauconite mineral, however, it contains thick black shale in its base and top. From this group, many marine fossils found in Ashiya group, are obtained.

They are as follow.

Glycymeris cisshuensis Makiyama

Chlamys ashiyaensis Nagao

Callista hanzawai Nagao.

Dosinia chikuzenensis Nagao.

In the middle part of the group, there are thick alternations of sandstone and siliceous or tuffaceous fine shale called "Honeishi".

Overlying this Honeishi zone, a glauconite-rich, green coloured sandstone zone (the Komanaki formation) having maximum thickness of 120 meters is found.

The Sasebo group overlying conformably on the marine deposits of the Kishima group is mainly composed of white sandstone and divided into six formations, which are known as Ainoura, Nakazato, Yunoki, Sechibaru, Fukui, and Nojima in ascending order. 
They are conformable but in Ainoura and Nojima, sometimes, unconformities are found.

The Ainoura and Sechibaru formations are in general terrestrial deposits but intercalated with marine deposits containing such marine fossils as Glycymeris cisshuensis Mak., Callista matsuraensis Nagao, Turritella karatsuensis N. and Chlamys ashiyaensis $\mathrm{N}$. which are found in the Kishima formation.

The other formations of the Sasebo group are terrestrial in origin and contain several brackish- or freshwater-fauna such as Corbicula, Viviparus and Lamprotura.

\section{Sakito-Matsushima coal field}

The field extends under the sea from the west coasts of the islands, Sakito, Oshima and Matsushima. The Palaeogene sediments of this field are brocken by the faults extending from the northwest to the east-west and have strikes varying from the northnortheast to the north-south or the north-northwest and dip $10^{\circ}$ to the west.

They are divided into five groups, Akasaki, Terashima, Matsushima, Nishisonoki and Korose in ascending order.

The Akasaki group contains the reddish purple formation, and is found at the very narrow area in the island Terashima.

The Terashima group contains some coal seams in the alteranation of sandstone and shale.

On this groups, the Matsushima group unconformably lies, and its lower division is mainly made up of white sandstone and shale and its upper division is mainly made up of white sandstone and has some thick coal seams.

The group is overlain by the marine deposits, the Nishisonoki group which contains such marine fossils as Glycymeris cisshuensis Mak., Turritella karatsuensis Nagao, Venericardia subnipponica Nagao, Chlamys ashiyaensis var., and etc., therefore, the group is correlated with the Ashiya group of the Chikuho coal field.

The Kurose group probably correlated with the Sasebo group occurs in a north-western small area of the Öshima island and is made up an alternation of sandstone and shale.

10. Takashima coal field 
The palaeogene sediments of this field extend also under the sea from the west coast of the Nomo peninsula. They attain a thickness of 1,700 meters and are composed of sandstone, conglomerate, and shale, and are divided into three groups, Akasaki, Takashima, and Iōjima in ascending order.

The relation between the two groups, Iōjima and Takashima is not determined because the former is isolated from the latter by the sea water on the surface, however the boring data in the Iojima island have not shown the unconformable relationship.

The Akasaki contains also the reddish purple formation, however, in the southern area of the Nomo, the reddish purple formation is scarcely found.

The upper division of the Takashima group (the Hashima formation) is terrestrial in origin and has thick coal seams containing fossil flora such as Glyptostrobus sp., Osmanda lignitum Giebel, Nelumbium sp., Salvania formosa $\mathrm{Hr}$. and etc. which are described by A.G. Nathorst and R. Florin.

The main part of the lower one (the Futagojima formation) is marine deposits having such marines fossils as Orthaulax japonicus Nagao, Turritella okadai Nagao, and etc., however, its upper part is terrestrial deposits containing Sabal nipponica Krysht., Lastraea japonica Krisht, and Acrosticum hesporium Newberry which are also described by A. Kryshtofovich.

The Iojjima group is marine deposits consisting mainly of sandstone, however, the lower part (the Okinoshima formation) is made up of coarse grained sandstone and conglomerate. It is remarkable that the conglomerates of the formation contain many subangular coal boulders.

\section{Amakusa coal field}

The field contains not only the Amakusa islands but also the western area of the Uto peninsula and their neighbouring islands. The palaeogene sediments overlie unconformably the Cretaceous deposits and the other older basement complex and are overlain in part by the Neogene Tertiary or the Aso lava and are intruded by the younger intrusive igneous rocks.

The sediments have been compressed into a series of the north-northeast trending folds and are devided into three groups, Akasaki, Kamishima and Sakasegawa in ascending order. 
The Akasaki group is terrestrial deposits consist chiefly of the reddish purple formation (the Akasaki formation) in the island Kamishima, Uto peninsula and their neighbourghing islands, however the group is marine depodits (the Fukami formation) composed of thick sandstone-beds and intercalated shale or conglomerate rarely containing fossil foraminifera, in the Shimoshima island.

The Kamishima group lies conformably on the Akasaki group, and the group is marine deposits in the lower and middle parts, however, it is terrestrial deposits in the upper part (the Toishi formation) containing coal seame.

The lower and middle parts of the Kamishima group in the Kamishima island attain a thickness of about 1.000 meters and can be divided into three formations, Tanasoko, Kusubo and Sumoto, but that in the Shimoshima island, is only 100 meters in thickness and can not be devided (the Shikiyama formation).

The Sakasegawa group is marine deposits, consist of glauconitic sandstone in its lower part (the Itchoda formation), however, black shale in its upper part (the Sakasegawa formation).

\section{Correlation}

As above mentioned, in the palaeogene of the northern Kyushu, there are several important fossiliferous beds. Some of them are comtemporaneous and ten fossil zones are found; They are as follow :

1. the lower Ariake fossil zone (Tab. 1)

2. the upper Ariake fossil zone (Tab. 2)

3. the lower Nōgata fossil zone (Tab. 3)

4. the upper Nogata fossil zone (Tab. 4)

5. the Iwasaki-Karatsu fossil zone (Tab. 5)

6. the Ōtsuji plant fossil zone

7. the Ashiya fossil zone (Tab. 6)

8. the Masaru fossil zone (Tab. 6)

9. the Yatake fossil zone (Tab. 6)

10. the Nojima fossil zone

The common species of the fossil zones and the formations containing the fossils zones are shown in the Table 1-6.

Through the fossils from the palaeogene of this district, the changes of the species are not remarkable in each fossil zones 
Table 1. Common Fossils collected from the Lower Ariake Fossil Zone

\begin{tabular}{lccc}
\multicolumn{1}{c}{ Name of formation } & $\begin{array}{l}\text { Shira. } \\
\text { take } \mathrm{f} .\end{array}$ & $\begin{array}{c}\text { Komeno- } \\
\text { yama } \mathrm{f} .\end{array}$ & $\begin{array}{c}\text { Futago- } \\
\text { jima } \mathrm{f} .\end{array}$ \\
\hline Batissa nagaoi Suzuki & $\times$ & $\times$ & $\times$ \\
Callista ariakensis Nagao & & $\times$ & $\times$ \\
Corbula (Cunaecorbula) kyushuensis N. & $\times$ & $\times$ & $\times$ \\
C. subtumida Nagao & $\times$ & $\times$ & $\times$ \\
Nerita subgranulosa Nagao & $\times$ & $\times$ & $\times$ \\
Polinices (Neverita) eocenica Nagao & $\times$ & $\times$ & $\times$ \\
P. utoensis Nagao & $\times$ & $\times$ & \\
Turritella miikensis Nagao & $\times$ & $\times$ & \\
T. okadai Nagao & $\times$ & $\times$ & $\times$ \\
Melania miikensis Nagao & & $\times$ & $\times$ \\
Orthaulax japonicus Nagaoa & $\times$ & $\times$ & $\times$
\end{tabular}

Table 2. Common Fossils collected from the Upper Ariake Fossil Zone

\begin{tabular}{lccc} 
Name of formation & $\begin{array}{c}\text { Nanaura } \\
\text { f. }\end{array}$ & $\begin{array}{c}\text { Hashima } \\
\text { N. }\end{array}$ & Toishí f. \\
\hline Batissa nagaoi Suzuki & & $\times$ & $\times$ \\
Corbula (Cunaecorbula) kyushuensis Nagao & $\times$ & $\times$ & \\
Orthaulax japonicus Nagao & $\times$ & $\times$
\end{tabular}


Table 3. Common Fossils collected from the Lower Nōgata Fossil Zone

\begin{tabular}{|c|c|c|c|c|c|}
\hline Spceies & $\begin{array}{c}\text { Itchoda } \\
\mathrm{f} .\end{array}$ & $\begin{array}{l}\text { Katsu- } \\
\text { tachi } \\
\quad \text { f. }\end{array}$ & $\begin{array}{l}\text { Okino- } \\
\text { shima } \\
\text { f. }\end{array}$ & $\begin{array}{l}\text { Kawa- } \\
\text { magari } \\
\text { f. }\end{array}$ & $\begin{array}{c}\text { Oyake } \\
\text { f. }\end{array}$ \\
\hline Nucula hizenensis Nagao & & & $x$ & $x$ & \\
\hline Lima (Acesta) nishiyamai (Yok.) & $\times$ & $\times$ & & & \\
\hline Pholadomya margaritacea (Sow.) & $x$ & $x$ & $\times$ & & \\
\hline Crassatellites fuscus (Yok.) & $x$ & $\times$ & & & \\
\hline Venericardia nipponica Yok. & $x$ & $\times$ & $x$ & & \\
\hline$V$. mandaica (Yokoyama) & $\times$ & $x$ & & & \\
\hline Pitaria kyushuensis N. & & & $x$ & $x$ & \\
\hline P. takashimaensis $\mathrm{N}$. & & & $x$ & $\times$ & \\
\hline Pinna asakiraensis N. & & & & $x$ & $x$ \\
\hline Phacoides sp aff. P. pullensis (Opp.) & & & & $x$ & $x$ \\
\hline Orthaulax japonicus N. & & & $\times$ & $x$ & \\
\hline Athleta (Voltspina) japonica N. & & & $\times$ & $x$ & \\
\hline A. (V.) nishimurai N. & & & $\times$ & $\times$ & $\times$ \\
\hline Pseudoperissolax cfr. blakei (Conrad) & & $\times$ & $x$ & $\times$ & $\times$ \\
\hline Aturia yokoyamai Nagao & & x & $x$ & $\times$ & $\times$ \\
\hline Naatilus japonicus Shimizu & & & $x$ & $x$ & \\
\hline Carcharias cfr. cuspidata (Ag.) & & & $x$ & $x$ & \\
\hline
\end{tabular}

Table 4. Common Fossils collected from the Upper Nōgata Fossil Zone

\begin{tabular}{|c|c|c|c|c|c|}
\hline Species Name of formation & $\begin{array}{c}\text { Sakase } \\
\text { gawa } \\
\text { f. }\end{array}$ & $\begin{array}{l}\text { Yotsu- } \\
\text { yama } \\
\text { f. }\end{array}$ & $\begin{array}{l}\text { Doshi* } \\
\text { yama } \\
\text { f. }\end{array}$ & $\underset{f .}{\text { Iōjima }}$ & $\begin{array}{l}\text { Utsu- } \\
\text { bogi } \\
\quad \text { f. }\end{array}$ \\
\hline Venericardia nipponica Yokoyama & $x$ & $x$ & $x$ & & \\
\hline Pholadomya margaritacea (Sow.) & $x$ & & & $\times$ & \\
\hline Cardium hizenensis Nagao & & & $\times$ & $x$ & $\times$ \\
\hline Corbula subtumida Nagao & & & $\times$ & & $x$ \\
\hline Athleta (Voltospina) japonica Nagao & $x$ & & $x$ & $x$ & $x$ \\
\hline Athleta (Voltospina) nishimurai Nagao & & & $x$ & $x$ & \\
\hline
\end{tabular}


Table 5. Cemmon Fossils collected from the Iwasaki-Karatsu Fossil Zone

\begin{tabular}{|c|c|c|c|c|}
\hline \multirow[b]{2}{*}{ Species } & \multicolumn{2}{|c|}{$\begin{array}{l}\text { Karatsu } \\
\text { fossil zone }\end{array}$} & \multicolumn{2}{|c|}{$\begin{array}{c}\text { Iwasaki } \\
\text { fossil zone }\end{array}$} \\
\hline & ri & 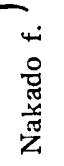 & 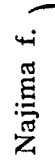 & 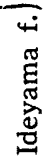 \\
\hline Nucula hizenensis Nagao & $x$ & & & \\
\hline Acila mirabilis Ad. \& Rve. var. ashiyaensis Nagao & $x$ & & & \\
\hline Chlamys sakitoensis Nagao & $x$ & $x$ & & \\
\hline Crassatellites matsuraensis $\mathrm{N}$. & $\times$ & & & \\
\hline Cardium hizenensis Nagao & $x$ & & & \\
\hline Cardium kishimaense Nagao & $x$ & & & \\
\hline Callista matsuraensis Nagao & $\times$ & & & \\
\hline Pitaria kyushuensis Nagao & $x$ & & & \\
\hline Corbula subtumida Nagao & $x$ & & & \\
\hline Athleta (Voltospina) japonica $\mathrm{N}$. & $x$ & & & \\
\hline Ostrea sakitoensis Nagao & & $x$ & & \\
\hline Venericardia subnipponica $\mathrm{N}$. & & $x$ & & \\
\hline Glycimeris cisshuensis Mak. & & $x$ & & \\
\hline Cultellus cfr. izumoensis Yok. & & & $x$ & \\
\hline Calyptraea mammilaris $\mathrm{N}$. & & & $x$ & \\
\hline Orthaulax japonicus Nagao & & & $x$ & $\times$ \\
\hline Turritella karatsuensis Nagao & & & $\times$ & \\
\hline Callista aff. ariakensis Nagao & & & & $x$ \\
\hline
\end{tabular}


Table 6. Common Fossils collected from the Ashiya, Masaru, and Yatake Fossil Zones
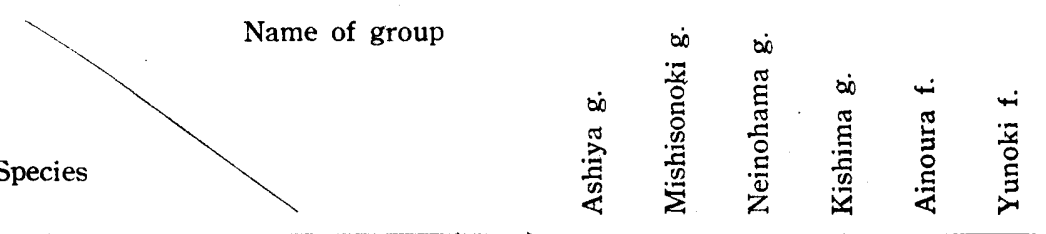

Linthia praenipponica Nagao

Dentalium ashiyaensis Nagao

Nucula hizenensis Nagao

Acila mirabilis Ad. \& Rve.

A. m. var. ashiyaensis Nagao

Glycimeris cisshuensis Mak.

Ostrea lunaeformis Nagao

Ch. ashiyaensis N. var denselineata N.

Ch. sakitoensis Nagao

Lima cfr. goliath Sowerby

Pholadonya margaritacea (Sow.)

Crassatellites yabei Nagao

Venericardia subnipponica Nagao

V. yoshidai Nagao

Cardium kishimaense Nagao

Callista hanzawai Nagao

C. matsuraensis Nagao

Pitaria kyushuensis Nagao

P. matsumotoi Nagao

Cyclina compressa Nagao

Polinices (Euspira) ashiyaensis N.

Turritella karatsuensis Nagao

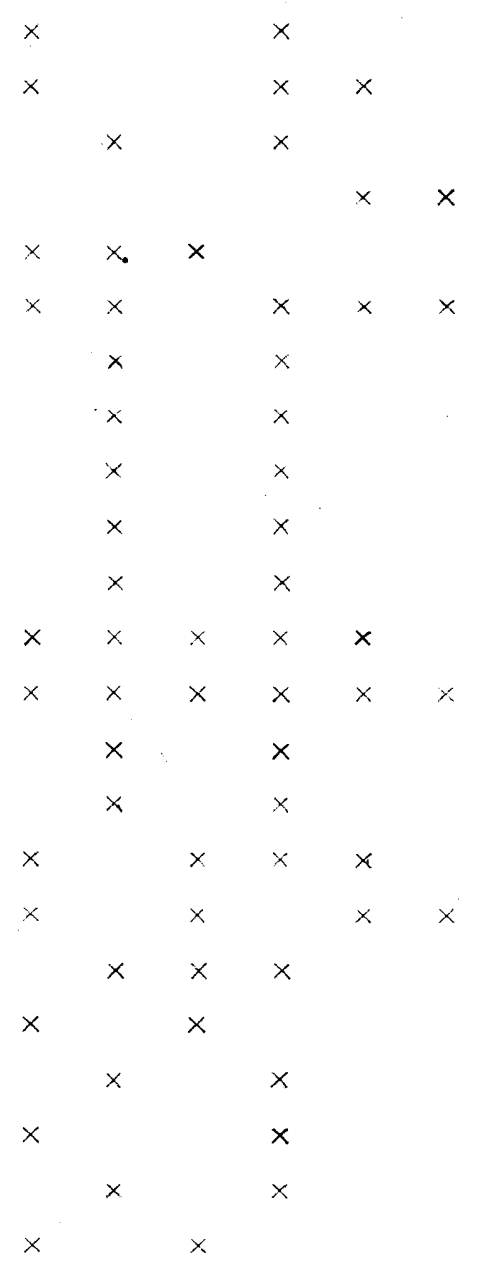

Carcharodon sp. near C. turgidus Ag. 
except that between the upper Nogata fossil zone and the newer ones. Namely the fossils found from the upper Nōgata fossil zone or the older ones but not from the newer ones are fairly numerous, and moreover the fossils found only from the newer ones are also numerous.

Thereby, one palaeontōlogical discontinuity will be found in there. (Tab. 7)

The palaeogene, moreover, contains not only above montioned fossil zones, but also the glauconite bearing formations, the coal seams, the light red formations, the reddish' purple formations and the so-called "Honeish" (tuffaceous or siliceous fine grained shale) beds. All of them can be treated as the key beds of the deposits.

In the southern coal fields such as Miike, Amakusa, Asakura, Takashima and Sakito-Matsushima, the Akasaki group containing the reddish purple formations have unconformably developed upon the basement complex.

Judging from their special colour tones made up under the same climatic conditions and the developments of the lower Ariake fossil zone in the Shiratake, Komenoyama, Futagojima formations, which lie conformable on the group, they are comtemporaneous with each other.

In the same area, the glauconite bearing formations, Itchoda, Katsutachi, Kawamagari and Okinoshima are found in the relatively upper parts of the deposits. They are correlated from their lithological characters and the fossils found in them (the lower Nōgata fossil zone).

The upper Ariake fossil zone is found in the Toishi, Nanaura, and Hashima formations uderlying those glauconite bearing formations.

Then, the formations between the upper Ariake fossil zone and the lower Ariake one must be correlated with the Ōmuta and Takashima groups.

The Sakasegawa, Yotsuyama, Doshiyama and Iōjima formations which contain the upper Nōgata fossil zone, must be correlated.

The reddish purple formations are also found at the base of the palaeogene deposits in the Fukuoka, Munakata, Kasuya and Chikuhō coal fields. Moreover, the red formations, Takeya, Ōnoi, 
Table 7. STRATIGRAPHICAL DISTRIBUTION OF SPECIES

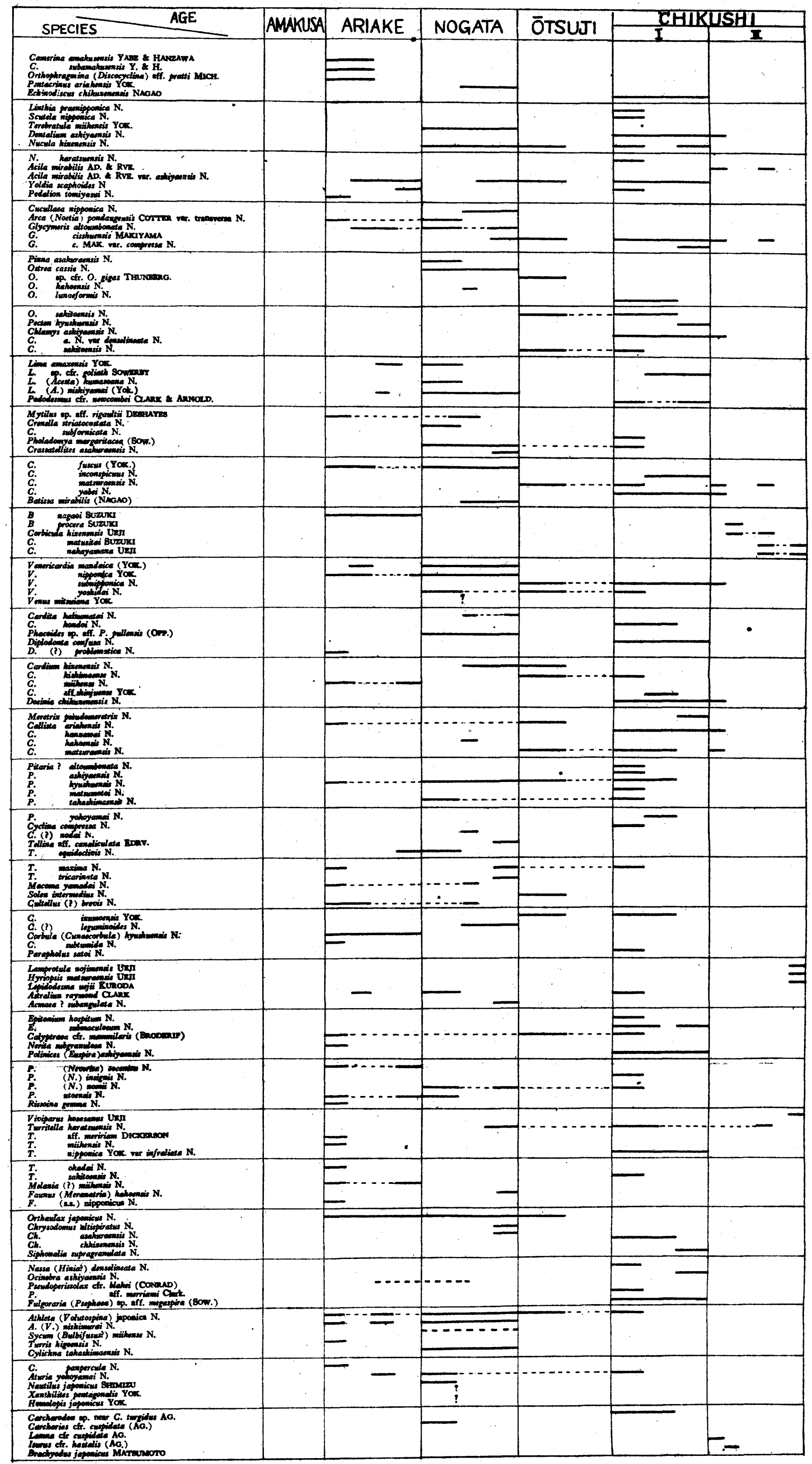


lower Umi, and middle Noma are found as the overlying formation of the purple ones.

Then the former formations must be correlated with each other as well as the latter for their lithological character and their stratigraphic sequences.

The Ötsuji, Shime, Sawara and Matsushima groups which lie unconformably upon the Nōgata, Kasuya, Fukuoka, and Terashima groups are found respectively in the each fields.

The lower parts of these former groups and the Yashiro formations in the Karatsu coal field contain the red formations and the marine deposits having the Iwasaki-Karatsu fossil zone, however, the upper parts of the group and the Yoshinotani are the coal bearing formations composed of thick white sandstone and coal seams in drift origin.

Then, they must be correlated respectively with each other by the reasons mentioned above.

On these groups., the Ashiya, Meinohama, Kishima, and Nishisonoki groups containing the Ashiya fossil zone are also developed and are contemporaneous in age.

The Oyake and Honso formations, have the glaucontic sandstone containing marine fossils such as Aturia yokoyamai N., Athleta (Voltispina) nishimurai N., Pinna asakuraensis N. and Phacoides sp. aff P. pullensis (Opp.) which are also found from the Kawamagari formation of the Asakura coalfield. As above mentioned the Kawamagari is correlated with the Katsutachi and Itchoda formations.

This fact may show that the sea under which the sediments of the Kawamagari formation deposited, extended the area to some parts of the Chikuhō coal field.

Then the Oyake and Honso formations must be correlated not only with the Kawamagari but also with the Katsutachi and Itchoda.

On the other hand, the Utubogi formation contains a marine fossil zone, belonging to the upper Noggata fossil zone.

Then the formation must be correlated with the Doshiyama, Iōjima, Yotsuyama and Sakasegawa formations. .

The Yashiro formation also contains marine fossils which are found from the Nakado formation together with the red formation 
which are found in the Ideyama, Najima, Uratani, so that the formation is correlated with the other such formations.

Then, the Utsubogi must be correlated not only with the Doshiyama, Iōjima, Yotsuyama, and Sakasegawa formations but also with the upper parts of the Nōgata, Munakata, Fukuoka groups. Thereby, the correlation of the palaeogene is shown as Table 8.

In the southern coal fields, each groups except the Akasaki, are made up of the deposits of one cycle of deposition.

In the northern coal field, it is also recognized, however, the Nōgata, Munakata, Kasuya, and Fukuoka group are chiefly terrestrial in origin, so that the cycles are not distinct.

Namely, the Kamishima, Ōmuta, Hōshuyama, Takashima and Terashima group are contemporaneous and the sediments of one cycle of deposition.

Then, they can be concluded as one stage - the Ariake stage.

In the same way, the Sakasegawa, Manda, Doshi, Iojima, Fukuoka, Kasuya, Munakata, and Nōgata group can be concluded as one stage-the Nōgata stage.

Similarly, the Matsushima, Ōchi (except the Utsubogi formation), Sawara, Shime and Ōtsuji can be concluded as. one stage-the Otsuji stage.

The Ashiya, Meinohama, Kishima and Nishisonoki groups are marine in origin and contain the Ashiya fossil zone, however, the Sasebo group is terrestrial in origin and contains the coal seams and the brackish- or fresh-water fossils.

The former groups may be recognized as the transgressive facies and the latter as the regressive facies, so that they make up one cycle of deposition and also can be concluded as one stage -the Chikushi Stage.

From their lithological character, the Akasaki groups of the southen coal fields may be concluded as one stage-the Amakusa stage.

As above mentioned, there is one palaeontological discontinuity between the two fossil zones-the upper Nōgata and the IdeyamaKaratsu fossil mones.

Then the Amakusa, Ariake and Nogata stages may be concluded as one series-the Shiranuri series. Similarly, the Otsuji and the Chikushi stages as one series-The Genkai series. 


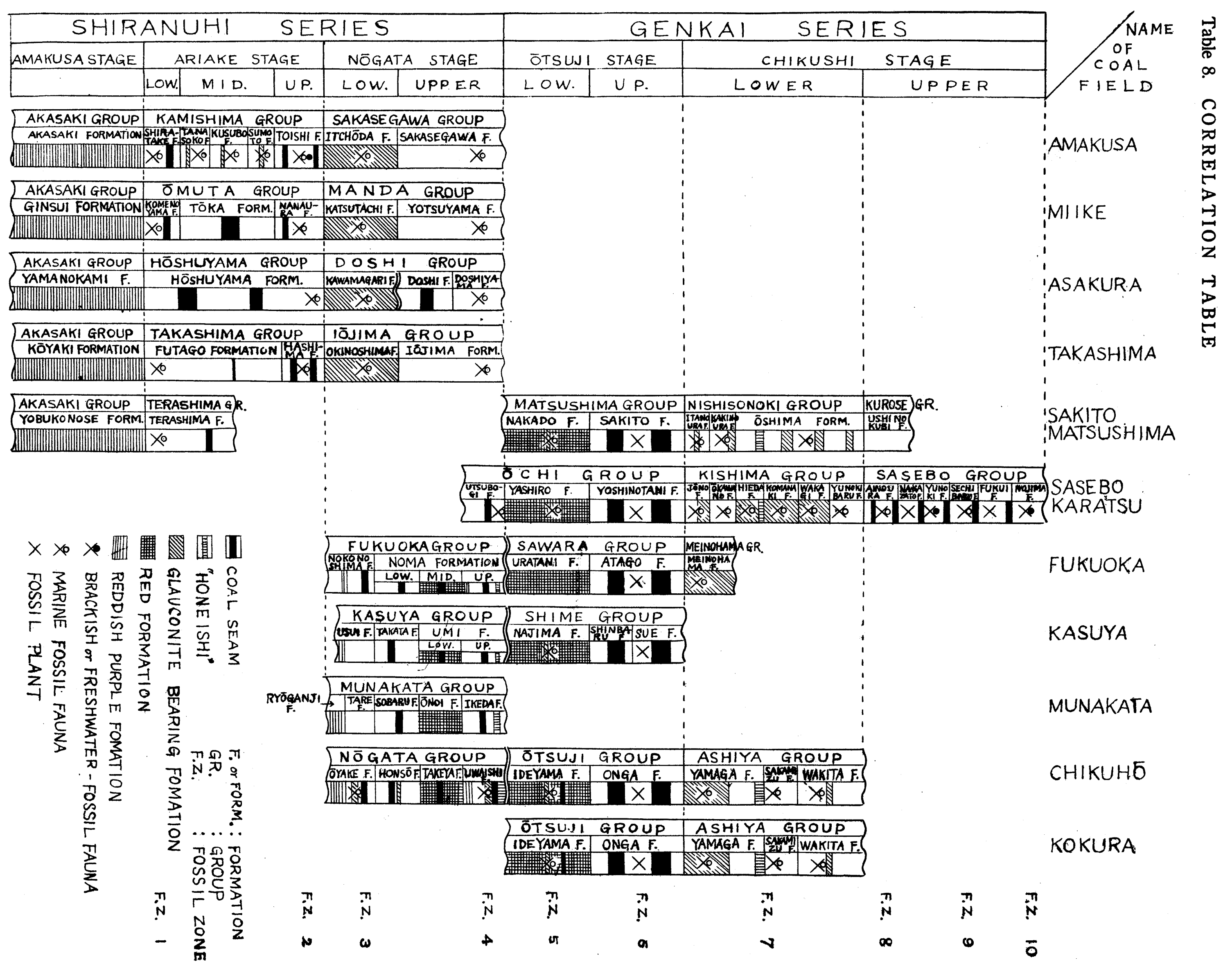


In concluding, the writer wishes to express his best thanks to Professor S. Yamane and the late Professors, K. Watanabe and K. Sugi for their suggestions and advices.

His most sincere thanks also due to Professors K. Kinoshita, T. Yoshimura and T. Matsumoto of the Kyushu University and Dr. K. Sakakura of Mitsubishi Mining Company, for their valuable helps recieved and suggestions, encouragements, and criticisms.

Finally, the writer wishes to express his thanks to the Department of Education for the research grant. 